\title{
Impact of Mid-Himalayan Watershed Development Project on its Beneficiaries in North-western Himalayas: A case of Himachal Pradesh
}

\author{
Amit Guleria $^{1^{*}}$, A.K. Randev ${ }^{2}$ and Pardeep Singh ${ }^{2}$ \\ ${ }^{1} P A U$, Ludhiana, India \\ ${ }^{2}$ Dr. Yashwant Singh Parmar University of Horticulture and Forestry, Nauni, Solan HP, India
}

*Corresponding author

\section{A B S T R A C T}

\section{Keywords}

Watershed, Land Use Pattern,

Cropping Pattern, Productivity, Income and Benefit Cost Ratio

\section{Article Info}

Accepted:

04 December 2020 Available Online: 10 January 2021

India's total farmers has 67.10 per cent marginal (below 1 ha.) followed by 17.91 per cent small (1-2 ha.). Indian agriculture thus dominated by marginal and small farmers who have very low land holdings, therefore raising productivity has been found to be the most important factor for increasing the income levels of farmers. Watershed management has been found to be influential programme for achieving this target. HP Mid-Himalayan Watershed Development Project - an integrated multisectoral Watershed Development Project has been operated in Mid Hills of Himachal Pradesh in 10 districts of the state from 2005 to 2017. The study has been carried out in the purposively selected Solan, Sirmour and Mandi districts of the state by selecting randomly a sample of 270 respondents comprising of 180 beneficiaries +90 non-beneficiaries, in terms of 2:1 ratio for the comparison of both the categories of respondents. This study has put emphasis on land use pattern, cropping pattern, productivity, income and benefit cost ratio. Results revealed that beneficiaries have put more area under cultivation $(0.56 \mathrm{ha})$ and have more irrigated land ( $0.36 \mathrm{ha})$ as compared to non-beneficiaries $(0.20 \mathrm{ha})$ which lead to increase in cropping intensity $(196.51 \%)$ on their farms. The study recommends that positive impact to be recorded on farmers' productivity and benefit-cost ratio of important crops as of project and investigation should be intensified at the farm level for growers to benefit.

\section{Introduction}

The Indian Himalayan Region (IHR) plays a vital role in sustaining life. It is important to the 50 million people who lives on its slope, and equally but less visibly important to nearly 1.2 billion people, a fifth of the world's population who depend on its downstream river basins. Another 3 billion rely on it indirectly in terms of food and energy production. The 11 mountain and hill states constitute almost 20.3 per cent of the total land mass of the country. Approximately 4 per cent (Census of India, 2011) of the Indian population live in the mountain states of Jammu and Kashmir, Himachal Pradesh, Uttarakhand, Sikkim, Arunachal Pradesh, Nagaland, Manipur, Meghalaya, Mizoram and the hill district of Assam, Tripura and West Bengal. Keeping in mind the geographical aspects of the hills states where the forest cover areas are large and vast, and the 
majority of the people living in these areas depend upon it for the livelihood. Forest becomes a centric focus. The protection of the livelihood comes in contrast with the conservation of forest, and how the existing forest rules and issues may aid in the development of the hill states. These are enormous prospects in the hill and mountain states for a thriving eco-tourism and mountain agriculture.

Himachal Pradesh located in North Western Himalayas of India, has a geographical area of 55,673 sq. Km with cultivated land 543365 hac (GOI, 2017). The State of Himachal Pradesh characterized by undulating, highly erodible and degrading tracts, has about 80 percent of cultivated land as rainfed (E\&SD, 2017), hence the watershed approach has been found to be the most suitable approach for development of such hilly areas. The approach has been found to be holistic, multidisciplinary and integrated involving close coordination of different activities/departments. In the past, planning based on administrative units has failed to take in to account the peculiar problems, resulting from the historical process of overexploitation of various natural resources in each locality.

Watershed management has been considered to be a process of planning, organizing and rationalizing land and other resources in command areas of a watershed to provide needed goods and services, simultaneously, conserving soil, water and other natural resources. The interrelationships among land use, soil and water, and the linkages between upstream and downstream area have been given an explicit significance in watershed management approach. Thus, watershed management has been found to focus on using resources in a productive and sustainable manner. The primary objective of watershed management projects has slows down or if possible, reverses the man made degradation which has been mostly manifested in accelerated run-off usually with heavy sedimentations, reduced agricultural productivity and progressive removal of vegetative cover on non-arable lands. The watershed management projects internalize the externalities caused by flooding from a large number of seasonal torrents every year and there have been heavy investments on account of compensations by Central and State Governments.

The Government of Himachal Pradesh has launched many watershed development projects financed by national and international donor agencies with a view to rehabilitate the degraded environment and improve the economy of the state. The Mid-Himalayan Watershed Development Project (MHWDP) has been operated in H.P. from 2005 to 2017, covering about 63.64 per cent to the geographical area of the state (E\&SD, 2016). It has been considered essential to assess the impact as well as the distribution of such impacts among the targeted population, inhibiting the command area where project interventions have been completed during the last about 12 years. Estimation of different impacts of watershed development project has based on land use, literacy rate, cropping intensity, crop productivity, changes in household income, households' expenditure and changes in living standards. This article deals with changes in the socioeconomic parameters of selected households and impact of project interventions on land use, irrigation status, cropping pattern and productivity. It reveals that changes in benefit cost ratio of the important crops and incremental benefits on beneficiaries' farms.

\section{Materials and Methods}

HP Mid-Himalayan Watershed Development Project - an integrated multi-sectoral 
Watershed Development Project has been implemented in Mid Hills zone of Himachal Pradesh with the assistance of the World Bank. The Project became operated in 10 districts of the state from 2005 to 2017 so as cover 710 Gram Panchayats of 46 Development Blocks. Purposive sampling has been adopted to select three districts namely Solan, Sirmaur and Mandi districts (Figure 1) out of 10 districts, because these three district represent 17 development blocks out of 42, comprising 40.4 per cent of the total command area and selected on the basis of varying climatic conditions which represents the overall impact of the project interventions in the total command area. Multistage stratified random sampling has been adopted to select the sample size. At the first stage, two development blocks from each district have been selected comprising 35.3 per cent of the total development blocks. At the second stage, list of gram-panchayats has been prepared and a sample of three grampanchayats from each block has been selected. Thus, 18 Gram panchayats have been selected from the six blocks. At the third stage, a sample of 10 farmers from each gram-panchayat, thus a sample comprising of 180 farmers have been ultimately selected by adopting probability proportion method. Simultaneously, a sample of 90 nonbeneficiaries have been selected from the adjacent panchayat unaffected by the project interventions. The data have collected based on personal interview of household heads through pre-tested schedule. The socioeconomic parameters such as demography (Average size of family, sex ratio, dependency ratio, literacy rate and literacy index), land use pattern, cropping pattern, livestock inventory, crop productivity, total household income, net income from agricultural and non-farm activities and benefit cost ratios have been used in the study. All the information has been collected through field visits during 2016-17. Baseline data have been collected from Agricultural census, 2005-06, Directorate of land records, Himachal Pradesh and Statistical outline of Himachal Pradesh, 2005-06, Economics and Statistical department of Himachal Pradesh.

Simple statistical tools such as averages, standard deviation and percentages have been used to arrive at the results related to the study objectives. $t$ test has been used to study the significant difference in the crop productivity of important crops by using the following formula:

$$
\begin{aligned}
& t=\frac{\overline{X_{1}}-\overline{X_{2}}}{\sqrt{\sigma^{2}\left(\frac{1}{N_{1}}-\frac{1}{N_{2}}\right)}} \sim d f\left(N_{1}+N_{2}-2\right) \\
& \sigma^{2}=\frac{N_{1} \times \sigma_{1}^{2}+N_{2} \times \sigma_{2}^{2}}{N_{1}+N_{2}-2}
\end{aligned}
$$

Where,

$\overline{X_{1}}=$ Average crop productivity of beneficiaries

$\overline{X_{2}}=$ Average crop productivity of nonbeneficiaries

$\mathrm{N}_{1}=$ Number of the beneficiaries cultivated the given crop

$\mathrm{N}_{2}=$ Number of the non-beneficiaries cultivated the given crop

$\sigma^{2}=$ Pooled variance

$\sigma_{1}^{2}=$ Variance of crop productivity for beneficiaries

$\sigma_{2}^{2}=$ Variance of crop productivity for nonbeneficiaries

Gini concentration ratio and Lorenz curve have been used to examine the impact of the 
project on household income distribution. The quantitative measure of Gini Concentration Ratio is given as follow:

$\gamma=\frac{N-1}{N+1}-\frac{2}{N(N-1) \mu}\left(\sum_{i=1}^{n} P_{i} X_{i}\right)$

Where,

$\gamma=$ Gini Concentration Ratio

$\mathrm{N}=$ Total Number of Households

$\mu=$ Population mean's income

$\mathrm{P}_{\mathrm{i}}=$ Income rank $\mathrm{P}$ of person $\mathrm{i}$ with income $\mathrm{X}$

This effectively gives higher weight to poorer people in the income distribution helping to satisfy the transfer principle (i.e. the measured inequality should decrease, when shifting income from a higher to a lower income household given the original order of income ranks).

\section{Assumptions of the study}

There has been no demonstration effect of project interventions on non-beneficiary farms.

The study has only pertained to assess the impact of project interventions whether beneficiary and non-beneficiary farms have located under same watershed.

\section{Results and Discussion}

\section{Description of the study area}

HP Mid Himalayan Watershed Development Project (HPMHWDP) has been operative in 5, 92,389 ha since 2005 and altitude ranging from 600 to $1800 \mathrm{~m}$, which lies between $30^{\circ}$ $22^{\prime} 40^{\prime \prime} \mathrm{N}$ to $33^{\circ} 12^{\prime} 40^{\prime \prime} \mathrm{N}$ latitude and $75^{\circ}$ $45^{\prime} 55^{\prime}$ " E to $78^{0} 10^{\prime} 15^{\prime \prime}$ E longitude. Soil has been found to be sandy loam to clay and have received annual rainfall of $1282.19 \mathrm{~mm}$.
The command area of the project has been divided into different land uses. Maximum geographical area has been found under forests $(40.40 \%)$ followed by net sown area (31.62\%); permanent pastures and other grazing land $(13.25 \%)$ and; barren and uncultivable land $(7.60 \%)$. Per cent share of net irrigated area to net sown area has been found to be 13.45 per cent and cropping intensity of study area has been found to be 168.00 per cent. Kuhl and tanks have been major sources of irrigation covering 11.17 and 8.26 per cent of net irrigated area. Total population has been found to be $13.15 \mathrm{lac}$, out of which 24.94 and 5.70 per cent were schedule caste and schedule tribes. The project has operated in 710 panchayats and 5,592 villages covering $2,73,108$ households. Literacy rate of the study area has been found to be 83.43 per cent. Total livestock population has been found to be 9,16,905 and human livestock ratio has been 1.43 as shown in Table 1 .

\section{Financial achievements of the project}

Out of total expenditure done by the project, it has been found that maximum expenditure has been done for construction of water harvesting structures i.e. 25.38 per cent among different project activities as shown in Table 2. The prime objective of the project has to increase availability of water for irrigation and to achieve this object for effective implementation of the project and for enhancement of physical productivities expenditure on construction of water harvesting structures has to be doubled, which lead to further increase in farm income.

\section{Socioeconomics}

Socio-economic parameters (Table 3) indicated socio-economic status of the selected households. It has been found that average family size of beneficiaries (5.54) was more than non-beneficiaries (5.44) but 
opposite results have been found in sex ratio. Non-beneficiaries (921) had higher sex ratio than beneficiaries (910) and in the baseline data it has been found to be 915 . Dependency ratio has been found out to be 2.74 and 3.45 in case of non-beneficiaries and beneficiaries respectively. The literacy rate has found to be 91.67 and 89.89 per cent in case of beneficiaries and non-beneficiaries and found much improvement when compared with baseline data $(74.90 \%)$. Literacy index indicate average quality of education of the study area. These parameters have been used only to show the socio economic status of the study area; not for the comparison between beneficiaries and non-beneficiaries because it has been found that there was no such intervention under the product for increasing the literacy status and sex ratio.

Average size of land holding has been worked out to be 1.36 ha on non-beneficiary farms and 1.29 ha on beneficiary farms. The irrigated area has been found to 176.92 per cent higher on beneficiaries than nonbeneficiaries, as a result, beneficiaries have put more area under cultivation ( 0.56 ha) leading to increase in their cropping intensity by 39.55 per cent as compared to nonbeneficiaries and 175.63 per cent cropping intensity has been found in baseline data. Singh et al., (2017) found that due to project interventions, cropping intensity has been increased significantly.

\section{Change in Land use pattern}

The total cultivated land under beneficiary farms has been found to be higher by 19.08 per cent as compared to non-beneficiaries (Table 4) which has been due to about 17.33 per cent lesser area under ghasnis/pasture and having more irrigation facility through construction of check dams and water harvesting structures on the beneficiary farms. This significant increase in cultivated especially irrigated land has been found due to construction of village ponds, Makowal structures, Masonry dams, water harvesting structure and earthen run off dams on 16.66, $10.00,6.67,25.00$ and 2.78 per cent of the total beneficiaries. The project high priority for roof rain harvesting, rejuvenation of village ponds, tanks and land development programme on percent farms on 11.11, 1.67, 14.44 and 4.44 per cent of total beneficiaries. More so, land put to non-agricultural use has been found to be less by 49.33 per cent on beneficiaries as compared to nonbeneficiaries. Desai et al., (1997) reported that project interventions helps the farmers to put more area under cultivation.

\section{Cropping pattern of food crops}

Cropping pattern in any region depends mainly on soil, altitude, micro-climate, availability of resources and management factors. The changes in the per cent share of area under different crops in the gross cropped area has revealed the extent of agricultural diversification on sampled farms. From the table 5 it has been depicted that there has been significant increase (49.09\%) in gross cropped area as compared to beneficiaries (1.06 ha) than non-beneficiaries (0.71 ha).

Per cent area under wheat and maize has decreased w.r.t. gross cropped area on beneficiaries than non-beneficiaries. But, there has been a significant increase in area under Kharif and Rabi vegetables. It has been also found that beneficiaries had shown shift from growing traditional crops like maize to high yielding crops viz. tomato (49.48\%), capsicum $(64.96 \%)$, ginger $(99.93 \%)$, pea $(110.88 \%)$ and garlic $(54.94 \%)$ due to increase in the irrigated area and providing seed of high value crops $(5-10 \mathrm{Kg}$ per household) by project. Ahmad et al., (2011) and Kushwah et al., (2016) revealed that 
increased in the irrigation facility, helps the farmers to shift from traditional crops to high value crops.

\section{Cropping pattern of fruits}

Beneficiaries have about 139.67 per cent higher area to be under fruits than nonbeneficiaries as shown in table 4. Apricot (30 $\%$ ) and Plum (23\%) have found the major fruit crops grown by the beneficiaries (Figure 2 ). This has been due to different land development programme, irrigation facility, homestead horticulture and high yielding cultivars given by the project to $4.44,50.00$, 19.44 and 22.22 per cent, respectively. New crop like pomegranate has also been introduced by beneficiaries may be due to impact of HPMHWDP.

\section{Cropping pattern of forest species}

Area and number of fodder crops under beneficiaries' farms have significantly increased as compared to non-beneficiaries (Table 6). It has been found that Bauhinia variegata, Leucaena leucocephala and Celtis australis have been grown more by beneficiaries as compared to nonbeneficiaries. This has also been due to project intervention for improving the productive potential through improvement of fodder and management practices $(3.33 \%)$, fodder augmentation demonstrations $(2.78 \%)$ and fodder conservation demonstrations (2.78 $\%$ ) leading to about on an average 36.18 number of forest species higher than nonbeneficiaries' farms. Semual et al., (2004) also reported that increase the availability of fodder due to project interventions.

Table.1 Profile of HP mid-Himalayan watershed development project

\begin{tabular}{|c|c|}
\hline Particulars & Project area \\
\hline Altitude (m) & $600-1800$ \\
\hline Latitude and Longitude & $\begin{array}{c}30^{\circ} 22^{\prime} 40^{\prime \prime} \mathrm{N} \text { to } 33^{\circ} 12^{\prime} 40^{\prime \prime} \mathrm{N} \text { and } 75^{\circ} 45^{\prime} 55^{\prime \prime} \\
\text { E to } 78^{0} 10^{\prime} 15^{\prime \prime} \mathrm{E}\end{array}$ \\
\hline Annual Rainfall (mm) & 1282.19 \\
\hline Soil texture & Sandy loam to clay \\
\hline Total geographical area (ha) & $5,92,389(100.00)$ \\
\hline \multicolumn{2}{|l|}{ Land Use Pattern (ha) } \\
\hline 1. Forests & $2,39,340(40.40)$ \\
\hline 2. Barren and Un-cultivable Land & $45,049(7.60)$ \\
\hline 3. Permanent Pastures and Other Grazing Land & $78,462(13.25)$ \\
\hline 4. Land put to Non Agriculture Land & $4,037(0.68)$ \\
\hline $\begin{array}{l}\text { 5. Land under Misc. Trees Crops not included in } \\
\text { Area Sown }\end{array}$ & $8,930(1.51)$ \\
\hline 6. Cultivable Waste Land & $14,979(2.36)$ \\
\hline 7. Other Fallow Land & $4,849(0.82)$ \\
\hline 8. Current Fallow Land & $10,435(1.76)$ \\
\hline 9. Net Sown Area & $1,87,307(31.62)$ \\
\hline 10. Area Sown more than Once & $1,27,368$ \\
\hline 11. Total Cropped Area & $3,14,675$ \\
\hline Net-Irrigated area (ha) & 25,199 \\
\hline \multicolumn{2}{|l|}{ Source wise irrigated area (ha) } \\
\hline 1. Kuhl (canals) & 2,313 \\
\hline 2. Tanks & 2,081 \\
\hline
\end{tabular}




\begin{tabular}{|l|c|}
\hline 3. Any other sources & 20,805 \\
\hline Cropping intensity (\%) & 168.0 \\
\hline Total population (lac.) & 13.15 \\
\hline Population density (person/km $\mathbf{k n}^{\mathbf{}}$ ) & 222 \\
\hline Schedule caste population (lac.) & 3.28 \\
\hline Schedule tribes population (lac.) & 0.75 \\
\hline Number of panchayats & 710 \\
\hline Number of villages & 5592 \\
\hline Number of households & $2,73,108$ \\
\hline Literacy rate $(\%)$ & 83.43 \\
\hline Livestock population (no) & $9,16,905$ \\
\hline 1. Per ha cultivated area & 4.89 \\
\hline 2. Per ha grazing land & 11.68 \\
\hline Human livestock ratio & 1.43 \\
\hline
\end{tabular}

Figures in parentheses indicate percentages to the total geographical area

Table.2 Total financial achievements of different project interventions under HP Mid Himalayan Watershed Development Project from 2005-06 to 2014-15

\begin{tabular}{|c|l|c|c|}
\hline S. No. & Project interventions & Grand total (in Rs. cr) & Percentage \\
\hline $\mathbf{1}$ & Institutional strengthening & 84.54 & 23.16 \\
\hline $\mathbf{2}$ & Plantation activities & 56.88 & 15.58 \\
\hline $\mathbf{3}$ & Soil conservation measures & 39.70 & 10.87 \\
\hline $\mathbf{4}$ & Water harvesting structures & 92.67 & 25.38 \\
\hline $\mathbf{5}$ & Productivity enhancement & 20.51 & 5.62 \\
\hline $\mathbf{6}$ & Livestock development & 21.82 & 5.98 \\
\hline $\mathbf{7}$ & Enhancing livelihood & 48.99 & 13.42 \\
\hline & Total & 365.10 & \\
\hline
\end{tabular}

Table.3 Important socio-economic parameters in the study area

\begin{tabular}{|c|l|c|c|c|c|c|}
\hline $\begin{array}{c}\text { Sr. } \\
\text { No. }\end{array}$ & Particulars & Unit & $\begin{array}{c}\text { Non- } \\
\text { beneficiaries }\end{array}$ & Beneficiaries & $\begin{array}{c}\text { Per cent } \\
\text { change }\end{array}$ & $\begin{array}{c}\text { Base line } \\
\text { data*** }\end{array}$ \\
\hline $\mathbf{1}$ & Average size of family & Number & $5.44 \pm 1.90 *$ & $5.54 \pm 2.49$ & 1.84 & 6.21 \\
\hline $\mathbf{2}$ & Sex ratio & & $921 \pm 221$ & $910 \pm 275$ & -1.19 & 915 \\
\hline $\mathbf{3}$ & Dependency ratio & & $1: 3.45 \pm 0.42$ & $1: 2.74 \pm 0.48$ & -20.58 & $1: 3.56$ \\
\hline $\mathbf{4}$ & Literacy rate & Per cent & $89.89 \pm 16.20$ & $91.67 \pm 12.55$ & 1.78 & 74.90 \\
\hline $\mathbf{5}$ & Literacy index & & $2.60 \pm 1.11$ & $2.69 \pm 0.80$ & 3.46 & 2.05 \\
\hline $\mathbf{6}$ & Average size of land holding & Hac & $1.34 \pm 0.52$ & $1.29 \pm 0.46$ & -3.73 & 1.96 \\
\hline $\mathbf{7}$ & Net cultivated area & Hac & $0.46 \pm 0.20$ & $0.56 \pm 0.24$ & 21.74 & 1.27 \\
\hline $\mathbf{8}$ & Irrigated area & Hac & $0.14 \pm 0.04$ & $0.36 \pm 0.15$ & 176.92 & 0.28 \\
\hline $\mathbf{9}$ & Un-irrigated area & Hac & $0.33 \pm 0.15$ & $0.20 \pm 0.08$ & -39.39 & 0.99 \\
\hline $\mathbf{1 0}$ & Cropping intensity & Per cent & $156.96 \pm 36.49$ & $196.51 \pm 11.49$ & 39.55 & 175.63 \\
\hline
\end{tabular}

*Mean \pm Standard Error, **Agricultural Census and Statistical abstract, Himachal Pradesh 
Table.4 Land use pattern of selected households ( $\mathrm{Ha}$.)

\begin{tabular}{|c|c|c|c|}
\hline Particulars & Non-beneficiaries & Beneficiaries & Per cent change \\
\hline \multirow[t]{2}{*}{ Cultivated area } & 0.45 & 0.54 & 19.08 \\
\hline & $(33.80)$ & $(41.62)$ & \\
\hline \multirow[t]{2}{*}{ Irrigated } & 0.13 & 0.34 & 156.47 \\
\hline & (9.97) & (26.44) & \\
\hline \multirow[t]{2}{*}{ Un-irrigated } & 0.32 & 0.20 & -38.40 \\
\hline & $(23.83)$ & $(15.18)$ & \\
\hline \multirow[t]{2}{*}{ Orchard Area } & 0.01 & 0.02 & 139.67 \\
\hline & $(0.66)$ & $(1.65)$ & \\
\hline \multirow[t]{2}{*}{ Irrigated } & 0.01 & 0.02 & \\
\hline & $(0.13)$ & $(1.56)$ & \\
\hline \multirow[t]{2}{*}{ Un-irrigated } & 0.01 & 0.00 & \\
\hline & $(0.53)$ & $(0.08)$ & \\
\hline \multirow[t]{2}{*}{ Forest land } & 0.07 & 0.05 & \\
\hline & $(4.89)$ & $(3.85)$ & \\
\hline \multirow[t]{2}{*}{ Ghasnis/Pastures } & 0.68 & 0.56 & -17.33 \\
\hline & $(50.63)$ & $(43.29)$ & \\
\hline \multirow[t]{2}{*}{ Fallow land } & 0.05 & 0.05 & \\
\hline & $(3.43)$ & $(4.21)$ & \\
\hline \multirow[t]{2}{*}{ Barran land } & 0.05 & 0.05 & \\
\hline & (3.53) & (3.78) & \\
\hline \multirow[t]{2}{*}{ Land put to non-agricultural use } & 0.04 & 0.02 & -49.33 \\
\hline & $(3.07)$ & $(1.61)$ & \\
\hline \multirow[t]{2}{*}{ Total Area } & 1.34 & 1.29 & \\
\hline & $(100.00)$ & $(100.00)$ & \\
\hline \multirow[t]{2}{*}{ Irrigated } & 0.14 & 0.36 & \\
\hline & (10.10) & $(28.01)$ & \\
\hline \multirow[t]{2}{*}{ Un-irrigated } & 1.20 & 0.93 & \\
\hline & (89.90) & $(71.99)$ & \\
\hline
\end{tabular}

Figure in parentheses indicate percentage to total

Table.5 Cropping pattern of food crops ( $\mathrm{Ha}$.

\begin{tabular}{|l|c|c|c|}
\hline Particulars & Non-beneficiaries & Beneficiaries & Per cent Change \\
\hline Wheat & 0.14 & 0.18 & 32.05 \\
\hline & $(19.61)$ & $(17.37)$ & -9.94 \\
\hline Maize & 0.15 & 0.14 & \\
\hline & $(21.61)$ & $(13.06)$ & \\
\hline Other & 0.00 & 0.05 & \\
\hline & $(0.00)$ & $(5.02)$ & 49.48 \\
\hline Kharif Vegetables & & & \\
\hline Tomato & 0.10 & 0.15 & 64.96 \\
\hline & $(14.20)$ & $(14.23)$ & \\
\hline Capsicum & 0.07 & 0.12 & \\
\hline & $(9.90)$ & $(10.96)$ & \\
\hline Ginger & 0.02 & 0.04 & \\
\hline
\end{tabular}




\begin{tabular}{|l|c|c|c|}
\hline Other & 0.03 & 0.05 & 71.00 \\
\hline \multicolumn{4}{|c|}{ Rabi Vegetables } \\
\hline Pea & 0.09 & $(4.39)$ & \\
\hline & $(12.65)$ & $(17.90)$ & \\
\hline Garlic & 0.07 & 0.11 & 54.94 \\
\hline & $(9.61)$ & $(9.99)$ & \\
\hline Other & 0.04 & 0.04 & \\
\hline & $(5.87)$ & $(3.44)$ & 49.09 \\
\hline Gross cropped area & 0.71 & 1.06 & \\
\hline & $(100.00)$ & $(100.00)$ & \\
\hline
\end{tabular}

Figure under parentheses indicate percentage to gross cropped area

Table.6 Cropping pattern of forest species

\begin{tabular}{|l|c|c|c|c|}
\hline \multirow{2}{*}{ Particulars } & \multicolumn{2}{|c|}{ Non-beneficiaries } & \multicolumn{2}{c|}{ Beneficiaries } \\
\cline { 2 - 5 } & Area (ha.) & Number & Area (ha.) & Number \\
\hline Grewiaoptiva & 0.06 & 11.38 & 0.05 & 10.41 \\
\hline Morus alba & $(37.28)$ & & $(25.17)$ & \\
\hline & 0.02 & 3.81 & 0.02 & 3.71 \\
\hline Bauhinia variegata & $(12.74)$ & & $(8.96)$ & \\
\hline & 0.01 & 3.06 & 0.02 & 4.54 \\
\hline Leucaenaleucocephala & $(8.37)$ & & $(8.79)$ & \\
\hline & 0.01 & 2.33 & 0.02 & 3.39 \\
\hline Celtisaustralis & $(7.95)$ & & $(8.20)$ & \\
\hline & 0.04 & 4.05 & 0.07 & 7.44 \\
\hline Other & $(27.58)$ & & $(35.97)$ & \\
\hline & 0.01 & 2.26 & 0.03 & 6.68 \\
\hline Total & $(6.08)$ & & $(12.93)$ & \\
\hline & 0.16 & 26.90 & 0.21 & 36.18 \\
\hline
\end{tabular}

Figure under parentheses indicate percentage to total

Table.7 Per cent change of crop productivity and its significance between beneficiaries and nonbeneficiaries

\begin{tabular}{|c|l|c|c|}
\hline S.No. & Crops & Per cent Change & t value \\
\hline $\mathbf{1}$ & Wheat & 13.64 & $8.68^{*}$ \\
\hline $\mathbf{2}$ & Maize & 30.08 & $26.23^{*}$ \\
\hline $\mathbf{3}$ & Tomato & 11.72 & $24.22^{*}$ \\
\hline $\mathbf{4}$ & Capsicum & 11.39 & $13.67^{*}$ \\
\hline $\mathbf{5}$ & Ginger & 12.15 & $6.89^{*}$ \\
\hline $\mathbf{6}$ & Beans & 10.27 & $14.27^{*}$ \\
\hline $\mathbf{7}$ & Pea & 13.19 & $12.89^{*}$ \\
\hline $\mathbf{8}$ & Garlic & 7.97 & $12.11^{*}$ \\
\hline $\mathbf{9}$ & Cauliflower & 7.26 & $5.20^{*}$ \\
\hline
\end{tabular}

$*$ p value $<0.01$ 
Table.8 Incremental benefits to farmers from the project (Rupees)

\begin{tabular}{|l|l|c|c|c|}
\hline Sr. No. & Particulars & Non-beneficiaries & Beneficiaries & Per cent change \\
\hline $\mathbf{1}$ & Net income from agricultural activities & 112708 & 179862 & 59.58 \\
\hline $\mathbf{2}$ & Net income from non-agricultural activities & 118545 & 124131 & 4.71 \\
\hline $\mathbf{3}$ & B/C ratio of important crops & & & \\
\hline & i. Tomato & 1.72 & 1.90 & 11.03 \\
\hline & ii. $\quad$ Capsicum & 1.69 & 1.81 & 6.84 \\
\hline & iii. $\quad$ Ginger & 1.95 & 2.06 & 5.32 \\
\hline & iv. $\quad$ Beans & 1.70 & 1.82 & 6.93 \\
\hline & v. Pea & 1.68 & 1.70 & 0.84 \\
\hline & vi. $\quad$ Garlic & 1.57 & 1.63 & 3.74 \\
\hline & vii. $\quad$ Cauliflower & 1.49 & 1.54 & 3.94 \\
\hline
\end{tabular}

Fig.1 Location map of the study area
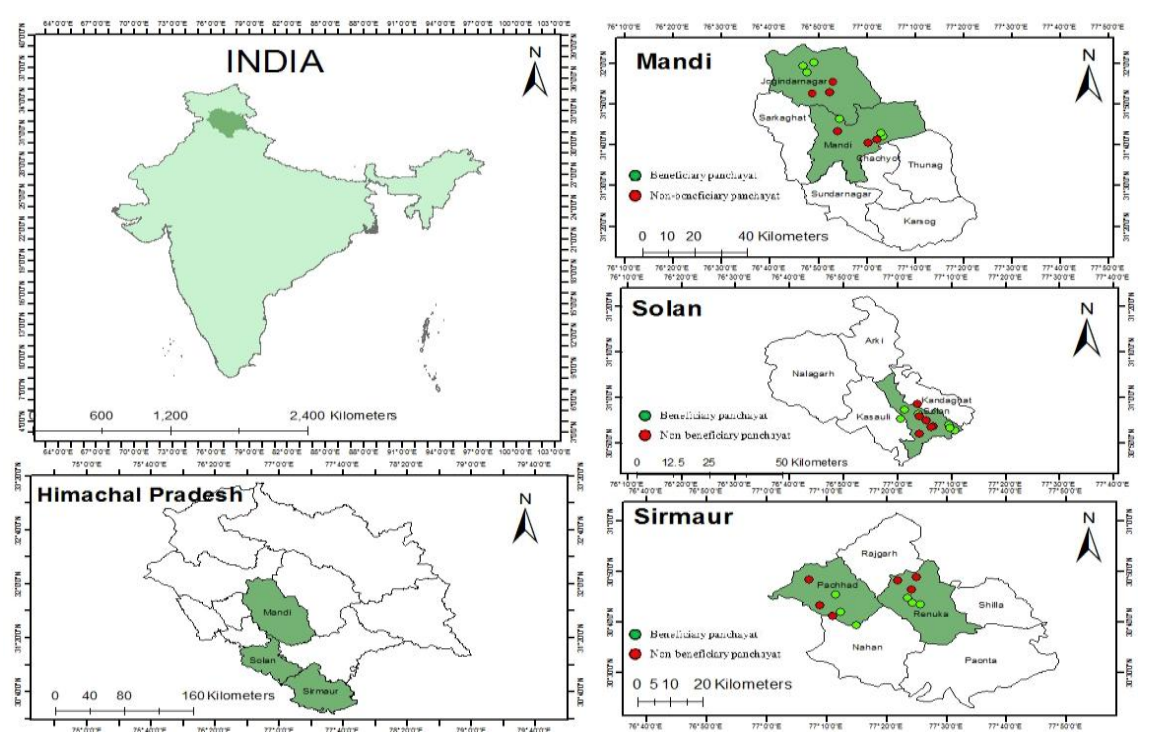

Fig.2 Cropping pattern of fruit crops
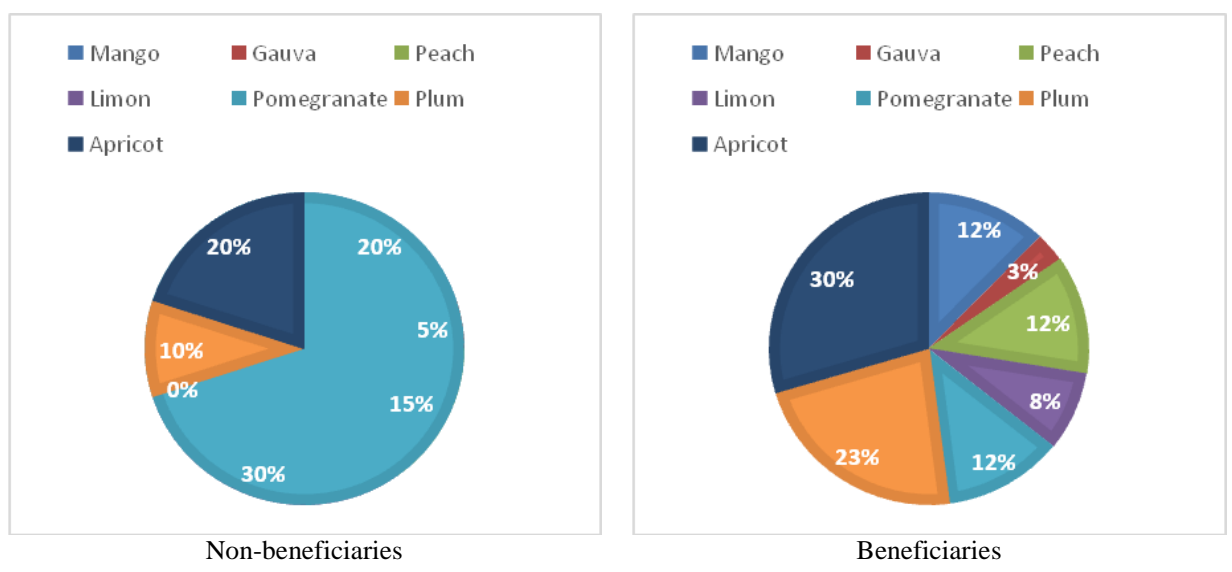
Fig.3 Livestock inventory of beneficiaries and non-beneficiaries

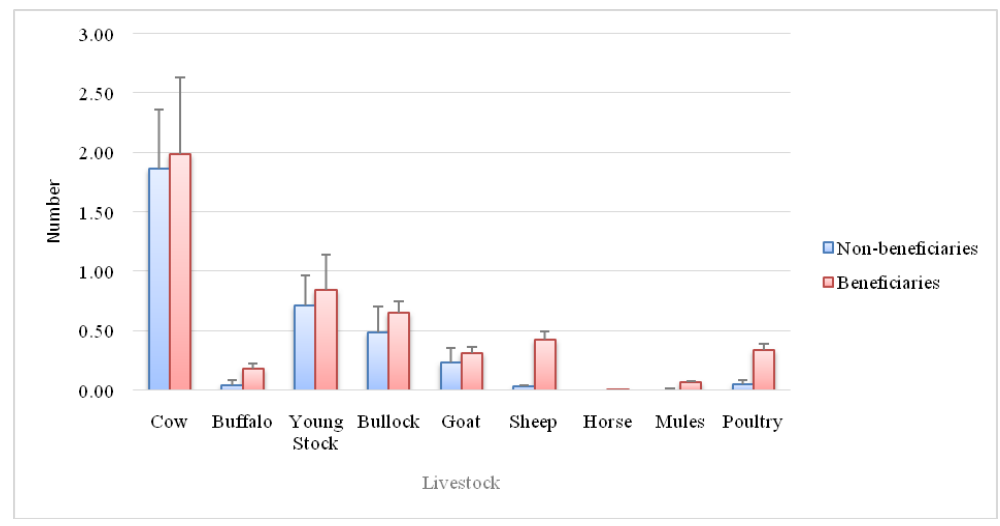

Fig.4 Crop productivity of major crops

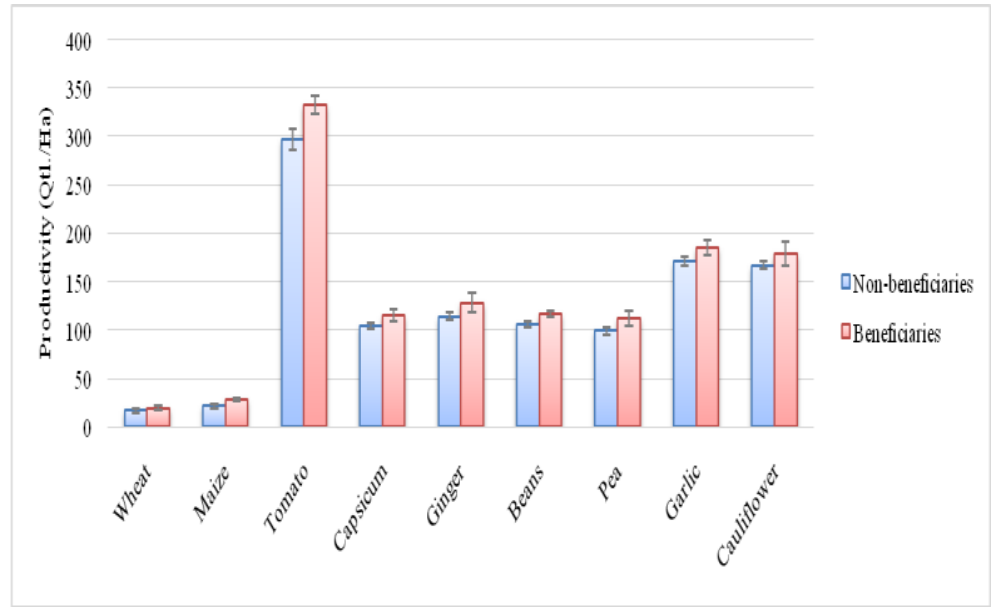

Fig.5 Composition of Household income of beneficiaries and non-beneficiaries

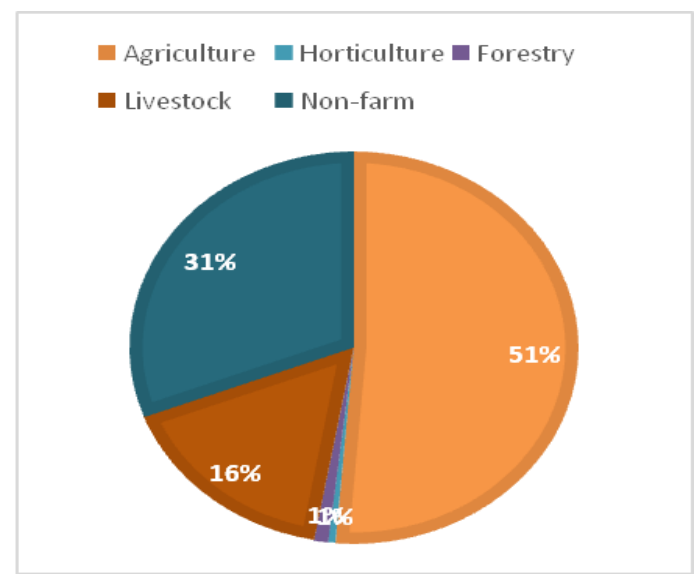

Non-beneficiaries

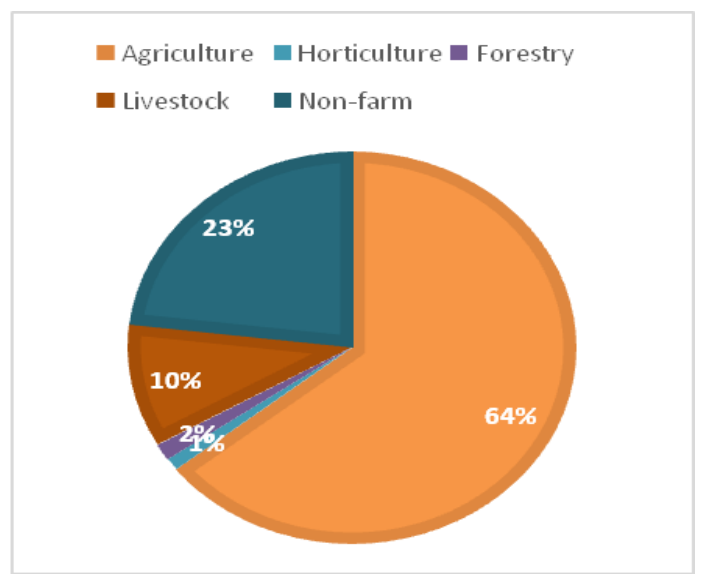

Beneficiaries 
Fig.6 Lorenz curve on income distribution among beneficiaries (B) and non-beneficiaries (NB)

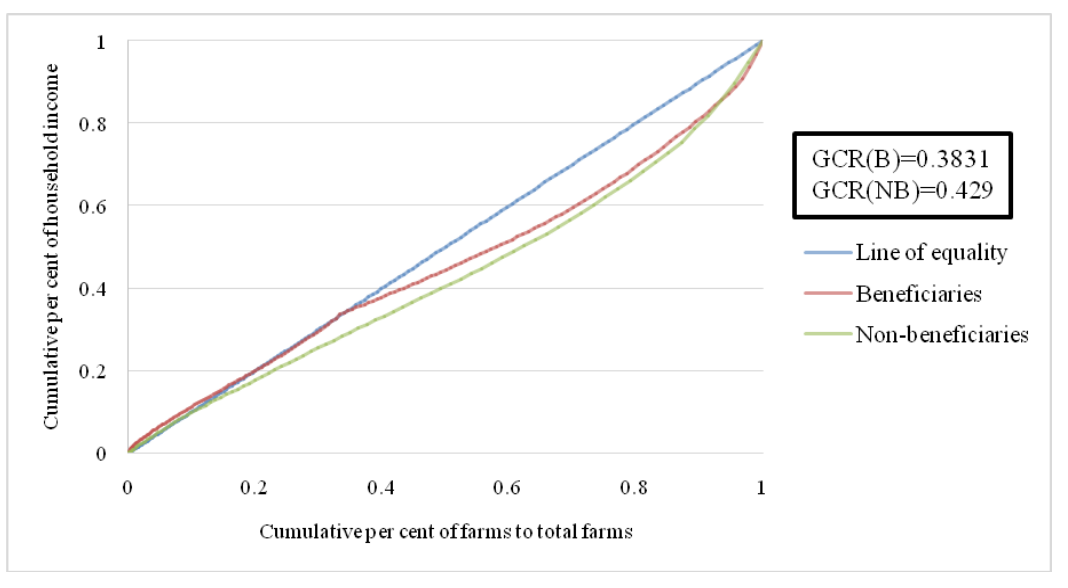

\section{Livestock status}

Livestock rearing has been considered to be an integral part of farming system in hilly states. They have been found not only direct providers of milk, meat, wool and manures but also main source of energy for ploughing and transport. In economic terms, they have been found to be a good supplementary source of income for the farmers through enhancement of physical productivity of crops by the use of farmyard manure. Figure 3 depicts that there has been a significant increase in livestock population on beneficiaries (4.82) as compared to nonbeneficiaries (3.43). This has been due to different livestock improvement programmes like, manger construction (30.56\%); chaff cutter $(33.33 \%)$, goatry $(5.56 \%)$ and poultry $(5.56 \%)$; seed (55.56), implements $(50.00 \%)$ and technology for on farm fodder cultivation $(2.78 \%)$; crop residue treatment $(2.78 \%)$ and different health cover and breeding viz. artificial insemination $(5.56 \%)$, organize veterinary camps $(3.33 \%)$, support to veterinary institutions and national breeding centre $(3.33 \%)$. These activities of project has led to reduction in open grazing, increased fodder production, increase milk production and less dependence on community land for fodder. Indirectly, providing assistance for construction of vermi compost pit (22.22\%) and khadi $(3.89 \%)$ had boost the beneficiaries for raring more livestock and especially sheep.

\section{Productivity issue}

The impact of HPMHWDP has been studied in terms of crops' productivity. It had been revealed from that maximum yield level had been found in tomato (298 and $333 \mathrm{q} / \mathrm{ha}$ ) followed by garlic (171 and $185 \mathrm{q} / \mathrm{ha})$, cauliflower (167 and $179 \mathrm{q} \mathrm{ha})$, ginger (115 and $129 \mathrm{q} / \mathrm{ha}$ ), beans (106 and $117 \mathrm{q}$ ha), capsicum (104 and $116 \mathrm{q} / \mathrm{ha})$, pea (100 and $113 \mathrm{q} / \mathrm{ha}$ ), maize (22 and $29 \mathrm{q} / \mathrm{ha}$ ) and wheat (17 and $20 \mathrm{q} / \mathrm{ha}$ ), respectively for nonbeneficiaries and beneficiaries (Figure 4). Major crops like tomato, garlic, cauliflower, ginger, beans, capsicum, pea, maize and wheat have shown 11.72, 7.97, 7.26, 12.15, 10.27, 11.39, 13.19, 30.08 and 13.64 per cent, respectively, enhance in the physical productivity levels of beneficiary farms as compared to non-beneficiary farms. The changes in crop productivity levels have been found to be statistically significant at one per cent level of significance ( $p$ value $<0.01$ ) on beneficiaries as compared to nonbeneficiaries (Table 7). The respondents have observed these changes have been found due to creation of water resources, soil conservation structures, assistance for vermi 
composting, distribution of farm implements and high yielding crops. Jat et al., (2008) and Kushwah et al., (2016) also found that productivity of different crops had increased due to watershed development project interventions.

\section{Changes in share of farm and off-farm income to the total household income}

To access the impact of the project on farm income, income from various sources has been calculated in terms of percent share of farm and off-farm income to the total household income. A perusal of Figure 5 indicated that annual household income has been found to be increased by 39.39 per cent from Rs. 536737 to Rs. 385068 of beneficiaries compared to non-beneficiaries.

This increase in total farm income has been attributed cumulatively to increased irrigation facility, providing different employment opportunity, different dairy development programs and providing support through nonfarm activities like knitting (26.67\%), swing (6.67\%), khadi $(3.89 \%)$, cutting and tailoring $(3.33 \%)$ and coal making through pine needles $(2.78 \%)$. It has also been found that agriculture having maximum contribution to total household income i.e. 64.00 per cent followed by non-farm activities (23.00\%), livestock $(10.00 \%)$, forestry $(2.00 \%)$ and horticulture $(1.00 \%)$. Similar trends had been found in case of non-beneficiaries.

\section{Incremental benefits}

A perusal of table 8 indicated that net income from agricultural activities has been calculated Rs. 179862 and Rs. 112708, for beneficiaries and non-beneficiaries, respectively. Beneficiaries' net income from agricultural and non-agricultural activities has been found 59.58 and 4.74 per cent more than non-beneficiaries, respectively. Per cent change in the $\mathrm{B} / \mathrm{C}$ ratio of beneficiaries as compared to non-beneficiaries for important crops viz. tomato, capsicum, ginger, pea, garlic and cauliflower has been found 11.03, 6.84, 5.32, 6.93, 0.84, 3.74 and 3.94 per cent, respectively. This has been due to increase the crop productivity through better irrigation facility, decrease in cost of production by availability of seed/planting material, assistance for vermi composting and farm implements.

\section{Pattern of income distribution}

The Lorenz curve for beneficiaries and nonbeneficiaries has been drawn and shown in figure 6. The Lorenz curve of beneficiaries has been found to be lie above that of nonbeneficiaries and the total household income of beneficiaries has been found higher than that of non-beneficiaries. The Gini Concentration Ratio has lower value (0.3831) for beneficiaries as compared to nonbeneficiaries (0.4296), indicating that the income has been found more evenly distributed for beneficiaries indicates better off status of beneficiaries than nonbeneficiaries, i.e. the gap between the rich and poor has been brought down. Lobo (1990), Deshpande and Reddy (1993), Singh et al., (1993), Kumar and Singh (2002) and Singh and Prakash (2010) revealed that watershed development projects helps to decrease the income inequality.

In conclusion the above facts clearly indicate that overall interventions of the project in the command area have positive and effective changes on land use system favourably through olericulture and with little attention to development of cereals and fruit crops. With availability of irrigation facility, farm implements, high plant yielding varieties, vermi compost and bio-fertilizers for beneficiaries has resulted positive effect on net sown area, gross cropped area, 
productivity and availability of nutrients. Livestock improvement programmes have increased the livestock status due to increase in fodder availability, veterinary training and other activities. Self-employment schemes such as knitting, swing, khadi, carpentry, goatry and poultry etc. have also lead to an increase in income of the beneficiaries significantly.

\section{Acknowledgments}

The authors are grateful to the Director of Research and Department of Social Sciences, Dr. Yashwant Singh Parmar University of Horticulture and Forestry, Nauni, Solan, Himachal Pradesh. The authors also thank to the line department officials and villagers in the study area for their cooperation during the survey.

\section{Disclosure Statement}

No potential conflict of interest was reported by the authors.

\section{Funding}

This work was supported by the Dr. Yashwant Singh Parmar University of Horticulture and Forestry, Nauni, Solan; Indian Council of Social Science Research, New Delhi.

\section{References}

Ahmad, J., Alam, D. and Haseen, S. 2011. Impact of climate change on agriculture and food security in India. International journal of Agriculture, Environment and Bio-technology 4(2): 129-137.

CoI. 2011. Census of India. Office of the Registrar General and Census Commissioner, India. Ministry of Home Affairs, Government of India. http://www.censusindia.gov.in/2011provresults/census2011_PPT_paper1.html

Desai, R. B., Girase, K. A. and Kokate, K. D. 1997. Assessment of micro watershed development on land use and cropping pattern in scarcity zone. Maharashtra Journal of Extension Education 16: 162-166.

Deshpande, R. S. and Reddy, V. R. 1993. Watershed development approach in fragile resource region: an analytical study of Maharashtra. Agricultural Situation in India, 48(3): 163-167.

E\&SD. 2016. Statistical year book of Himachal Pradesh. Economic and Statistics department of Himachal Pradesh.

http://admis.hp.nic.in/himachal/econo mics/

REPORTS/StatisticalYYearBook_2015 _16.pdf

E\&SD. 2017. Economic survey. Economic and Statistics department of Himachal Pradesh.http://admis.hp.nic.in/himacha 1/economics/pdfs/EconomicSurveyEng 2016_17_A1b. pdf

GOI. 2017a. Himachal Pradesh: the official website. http://himachal.nic.in/enIN/at-a-glance.html

Jat, S., Jain, S. K. and Rajout, A. M. 2008. Impact of watershed development programme in Madhya Pradesh. Indian Research Journal of Extension Education 8(1): 66-68.

Kumar, N. R. and Singh, P. 2002. Socioeconomic impact of Aril watershed development programme in Bareilly district of Uttar Pradesh. Journal of Agricultural Development and Policy 14(1): 20-32.

Kushwah, S., Mandal, S.S. and Kumari, S. 2016. Impact of watershed development programme in district Banka, Bihar. Journal of Progressive Agriculture 7(1): 72-75. 
Lobo, C. 1990. Watershed development: some implications for agrarian economic relations and rural employment. Social Action 40(2): 146162.

Semual, R. L., Nautiyal, S., Sen, K. K., Rana, U. S., Maikhuri, R. K., Rao, K. S. and Saxena, K. G. 2004. Pattern and ecological implications of Agricultural land use changes: A case study from Central Himalayas, India. Agriculture, Ecosystem and Environment 102: 8192.

Singh, K., Sandhu, H. S., Singh, N. and Kumar, B. 1993. Kandi watershed development project: a critical evaluation. Economic and Political Weekly 28(52): A122-128.

Singh, M., Gupta, B., Babu, S., Avasthe, R. K. and Das, S. K. 2017. Fodder, fuelwood consumption pattern and energy dynamics along elevation gradient in Giri Catchment, Himachal Pradesh, India. Indian Journal of Agricultural Sciences 87(2): 261-265.

Singh, S. B. and Prakash, N. 2010. Socioeconomic impact of watershed development project in Manipur. Indian Research Journal of Extension Education 10(1): 78-82.

\section{How to cite this article:}

Amit Guleria, AK. Randev and Pardeep Singh. 2021. Impact of Mid-Himalayan Watershed Development Project on its Beneficiaries in North-western Himalayas: A case of Himachal Pradesh. Int.J.Curr.Microbiol.App.Sci. 10(01): 382-396.

doi: https://doi.org/10.20546/ijcmas.2021.1001.047 